his Ph.D. from Duke University, where he met and married his wife, Adelaide.

Arriving at Sweet Briar College in Virginia as an instructor in government and economics in 1947, he began a remarkably successful career that spanned four decades. It was there that he and Adelaide raised their two children, Milan and Mary. In 1967 he won Sweet Briar's Kampmann Award for Excellence in Teaching. In 1973 he was nationally honored as an Outstanding Educator of the Year, and in 1985 he was honored as the first recipient of Sweet Briar's Distinguished Teaching Award, which was established by the College's Student Government Association. He was the recipient of many other awards and honors including the Distinguished Service Citation from Beloit College.

His research grants included Fulbright, Carnegie and Sweet Briar Faculty Fellowships. His scholarly interests were manifold, but he focused on two topics during the latter part of his career: Czechoslovakian politics between the two World Wars, and environmental policy in socialist countries. He wrote many articles on these subjects and at the time of his death was working on a book on Czechoslovakia. While his primary teaching responsibilities were in comparative politics, Hapala was very interested in interdisciplinary education and was instrumental in the development, at Sweet Briar College, of both an Asian Studies program and an Environmental Studies program. For many years, he was a Research Associate in the Russian and East European Center at the University of Illinois in Urbana.

When Milan Hapala came to Sweet Briar College, he may not have intended to stay for over 40 years. However, stay he did, and while there he raised a family and enriched the lives of countless students and colleagues. To honor his retirement and their commencement, the Class of 1990 invited him to deliver their commencement address.

Milan Hapala will long be remembered by those who knew him as a master teacher, a distinguished colleague, and an excellent friend.

Kenneth Grimm

Sweet Briar College

\section{Fritz Nova}

Fritz Nova died at the age of 80 on August 31, 1995. He earned his bachelor's and master's degrees at Haverford College in 1940, and his doctorate at the University of Pennsylvania in 1943. He was professor of political science at Villanova university from 1953 through his retirement in 1985, having served as chair of the department from 19621968. He then moved to Cumberland County, Pennsylvania, with his wife Coleta Halewyn Nova and taught parttime at Dickenson College, the Mont Alto campus of Penn State, and Shippensburg University.

Nova was born in Berlin; because of his Jewish background, he fled Germany in 1936. He later joined the U.S. Army and returned to Germany after the war to interrogate Nazi war criminals and others. His father and other relatives died in Nazi concentration camps. He had studied at the University of Bonn and the University of Milan in Italy. He won a Quaker scholarship to Haverford, which permitted him to receive a U.S. visa and safe refuge from the Nazis.

Nova was fluent in seven languages. He published six books, including one about Nazi theorist, Alfred Rosenberg, who was hanged by the Allies after World War Two. He once summed up his view of democratic society and his own accomplishments by saying, "It means respect for fellow men, participation in all levels wherever possible, the ability to be able to criticize and discuss the government, and toleration of others' views. I'm sure I've reached a great many of my students. I taught them something useful to their life."

The Medallion, awarded each year to the Villanova Political Science major with the best academic record, is named in his honor, as is the annual Social Science Forum lecture at Villanova University. He is remembered fondly and with respect by all who knew him.

Lowell S. Gustafson

Villanova University

\section{Donald Stuart Strong}

Donald Stuart Strong, Professor Emeritus of Political Science at the University of Alabama, died at age 82 on August 28, 1995, in Austin Texas.

Donald Strong was born in New York City on December 31, 1912. He did his undergraduate work at Oberlin College from which he graduated with a B.A. degree in 1934. He received his $\mathrm{Ph} . \mathrm{D}$. degree at the University of Chicago in 1939.

While Strong also served on the faculties of Western Reserve (1937-1939) and the University of Texas (19391946), most of his teaching career was spent at the University of Alabama where he taught from 1946 until his retirement as a Professor of Political Science on May 31, 1979. During his long career Strong also was recognized with visiting professorships at Brandeis, Tennessee, North Carolina State, and the University of Texas. He was a masterful teacher and his course on southern politics was one of the most popular on the campuses on which he taught. He was a very witty person and a delightful colleague.

Donald Strong first achieved national prominence when, in the late $1940 \mathrm{~s}$, he served as an assistant to V. O. Key, $\mathrm{Jr}$, in the development of the classic Southern Politics in State and Nation. Strong at this time was an Assistant Professor at the University of Alabama. For two summers he was engaged in field work with Key and, when this phase was done, he assisted Key in the preparation of the manuscript for submission to Alfred A. Knopf.

At the present time, when strong $\mathrm{Re}$ publican support in the South is taken for granted, it should be pointed out that Donald Strong was among the first to recognize the growth in GOP support and the foundations of this support. His major findings were published first in The 1952 Presidential Election in the South (1955) and Urban Republicanism in the South (1960).

Strong handled masterfully every subject to which he turned his attention, from his first examination of antisemitism in the United States in 1941 (the subject of his doctoral dissertation) to his last major reassessment of party realignment in 1977, two years before his retirement.

In addition to these subjects, Strong was also interested in the problem of African-American voting and glaringly exposed white supremist efforts to continue the subjugation of blacks through all sorts of disfranchising techniques. His findings in this area found principal expression in monographs, Registration of Voters in Alabama (1956) and Negroes, Ballots, and Judges (1955). Two of his journal articles were published in the American Political Science Review.

Donald Strong not only influenced the direction of political science research through his own writing, but through his editorship of the Journal of Politics. Strong brilliantly led the JOP from 1971-1974. The editorship followed his service as president of the JOP's sponsoring organization, the Southern Political Science Association, in 1970-1971. He also served on the executive council of the SPSA and was involved in committee work with the American Political Science Association. 